\title{
Serum Total Bilirubin Measurement
}

National Cancer Institute

\section{Source}

National Cancer Institute. Serum Total Bilirubin Measurement. NCI Thesaurus. Code C61031.

A quantitative measurement of the total amount of bilirubin present in a sample of serum. 